\title{
THE RELATIONSHIP BETWEEN THE INDIVIDUAL AND SOCIETY IN THE PLAYS OF TENNESSEE WILLIAMS
}

\author{
(C) N. V. Krylova \\ Petrozavodsk State University \\ 33, Lenin Street, 185910, Petrozavodsk, Republic of Karelia, Russia. \\ E-mail: nadkrylova@yahoo.com
}

\begin{abstract}
This article shows how dramatic works of Tennessee Williams serve as a clue to understanding the position of an artist in today's world and the relationship between the individual and society as expressed in his plays, interviews and memoirs. The characters of these plays are forced to reassess the quotidian values represented by all that is material and monetary against the backdrop of an examined life. The artist is viewed by the playwright as a true visionary who can see the light in the darkness, who can discover hope in the midst of despair and who can still find and create beauty in the everyday life of an increasingly violent world.
\end{abstract}

Keywords: Tennessee Williams, drama, individual vs. society, the role of an artist in relationship to the changing needs of society, the American dream, symbolism, text analysis.

America doesn't need artists because they don't count in America; artists have no more place in American life that the employers of the weekly pictorial magazine staffwriters have in the private life of a Mississippi novelist.

William Faulkner. On Privacy: the American Dream: What Happened to It.

They are hell-bent upon I, and such is the force of their unconscious deathwish and if all the artists and philosophers should unite to oppose them, by this opposition they could only enact a somewhat comical demonstration, suitable for the final two minutes of a television newscast: desperate farmers driving their pigs and goats up the stately Capitol steps would be scarcely more consequential... We do not wish to destroy. We are powerless to prevent.

Tennessee Williams. The Misunderstandings and Fears of an Artist's Revolt.

The title of the article is taken from an interview with Tennessee Williams during which the interviewer defined the role of an artist in a society as "an unacknowledged legislator of the world" [9, p. 50]. Tennessee Williams's own ideas on the issue, less categorical, are expressed in the epigraph to this article. This article studies the playwright's insight into the position of an artist in today's world and the relationship between the individual and the society as expressed in his plays and in some of his interviews and memoirs. The fabric of Williams's social life begs for close inspection. The current reassessment of many traditional values now occurring in America, combined with the many concomitant social and political cataclysms of the beginning of the $21^{\text {st }}$ century make this study especially timely. The inability to self-determine one's destiny, to outline the power over one's individual being no longer suppressed by the whims of a larger society is a mainstay of literature.

William Faulkner defines the American dream as "a sanctuary on the earth for individual man: a condition in which he could be free not only of the old established closed-corporation hierarchies of arbitrary power which had oppressed him as a mass, but free of that mass into which the hierarchies of church and state had compressed and held him individually thrilled and individually impo- 
tent" [6, p. 33]. In this definition Faulkner is rather pessimistic about the role of an artist in today's world calling him "the champion of the weak and the oppressed" for whom "America hasn't found any place" [6, p. 38]. Tennessee Williams shares Faulkner's bitter skepticism and speaks disparagingly of the rags-to-riches Cinderella story, as a destructive national myth, for the fate of his own characters is to miss the life's party.

Charles Bigsby, one of the best critics on Williams, supports this suggestion in his brilliant analysis of The Glass Menagerie. Acknowledging the political and social dimensions of Williams's plays, he concludes "At the same time [Williams] was wedded to art, whose power does lie in its ability to outlive even the traumas of history" [5, p. 43].

The choice of society's outcasts as the subject was not accidental. Not only is it connected with his own "inner immigration" caused by family dramas and homosexuality leading to the theme of escape in his plays, but, more importantly, it reflects his message to contemporary society, his profound existential despair. Williams's works represent a cry against the oppressors of the human spirit and asserts the right to be different and weak in the realm of the American dream, the realm of financial and social success.

The play that best illustrates this point is Camino Real, the play that was greatly underestimated and severely criticized during Williams's lifetime. In The Cambridge Companion to Tennessee Williams, edited by Matthew C.Roudané, Jan Balakian describes Camino Real as an "allegory about the fifties" [4, p. 67], the time when the romantic ideals of valor, nobility and honor gave way to desperation. Interviewed on the subject, Williams said that the play had presented the dilemma of an individual caught in a fascist state and was an expression of his belief in the difficulties of romanticism in a predominantly cynical world [8]. The play was attacked and labeled as anti-American and leftist. For Williams, however, the Red Scare became analogous to the "real road" in his play, where fascism crushes outcasts, rebels, homosexuals, prostitutes, dreamers, writers, idealists, and simply those who are weak, lonely or emotionally disturbed.

Camino Real's plea for compassion was a message for the American society of the 1950-s. The message was either misunderstood or rejected; the play received vitriolic reviews, was derided for its symbolism, language and one-dimensional characters. Williams records that at each performance people would "stamp out of the auditorium, with little regard for those whom they have had to crawl over, almost as if the building had caught on fire, and there have been sibilant noises on the way out and demands for money back if the cashier was foolish enough to remain in his box" [3, p. 69]. In the foreword to Camino Real the playwright fails to explain the reasons for the play's unfortunate fate, but a good critical analysis might unveil some of the misunderstandings caused by the play's stage representation.

Regardless of its aesthetic properties, the play might be looked upon as a metaphor for the United States or for any consumer society at large [7, p. 105]. We find here allusions to consumerism, mass media and bureaucracy shown in the sad context of deep existential crisis.

We come across a series of paralleled rhetorical questions parodying pseudo-psychological commercials: "Do you feel yourself to be spiritually unprepared for the age of exploding atoms? Do you distrust the newspapers? Are you suspicious of governments?.. Does further progress appear impossible to you? Are you afraid of anything at all? Afraid of your heartbeat? Or the eyes of strangers! Afraid of breathing? Afraid of not breathing? Do you wish that things could be straight and simple as they were in your childhood?.." [1, p. 766-767]. It is quite ironic that the hard sell adver- 
tisement belongs to the gypsy who was offering her daughter to strangers. The satiric tone of the passage is reinforced later on as Kilroy finds out he is swindled by the fortune-teller:

Kilroy: How about my change, Mamacita?

Gypsy: What change are you talking about?

Kilroy: Are you boxed out of your mind? The change from that ten spot you

trotted over to Walgreen's?

Gypsy [counting on her fingers]: Five for the works, one dollar luxury tax, two for the house percentage and two more pour la service! - makes ten! Didn't I tell you?

Kilroy: What kind of a deal is that?

Gypsy [whipping out a revolver]: A rugged one, Baby! [1, p. 819].

More than one character in the play serves as the author's mouthpiece. In fact, most critics accused Williams for making his schematic characters more a set of attitudes than individuals [10, $\mathrm{p}$. 183]. The characters can be roughly divided into three categories: decadents (Casanova, Marguerite, Baron de Charlus), outcasts and idealists (Kilroy, Byron and Don Quixote). For Williams the essential ambiguity of man in the twentieth century culture was alienation of self from a society filled with contradictions - personal ones, contradictions between characters, between an individual and the society, cultural contradictions. Williams reinforces the characters' internal contradictions. Thus he has his major characters observe themselves as though from an inner distance during their monologues and soliloquies.

Despite the play's seemingly dreamlike qualities and characters, Williams gives his allegory a conscious purpose which he articulates mostly through the characters of Don Quixote ("old meanings will be remembered and possibly new ones discovered"), of Kilroy and Casanova. Jacques Casanova speaks harshly of the imaginary society where "any exchange of serious questions and ideas between persons from opposite sides of the plaza" is inconceivable here [1, p. 775], and if "you have a spark of anarchy in your spirit" it will not be tolerated as "nothing wild and honest is tolerated here" [1, p. 784]. It is only natural that the airplane everyone wants to escape on is called The Fugitivo, as no one wants to live on the Camino Real. The place is ruthless toward individuals: "Now you know what is done to a body from which the soul has departed on the Camono Real! - Its disposition depends on what the Streetcleaners happen to find in its pockets. If its pockets are empty as the unfortunate Baron's turned out to be, and mine are at this moment - the "stiff" is wheeled straight off to the Laboratory" [1, p. 775]. Any attempt at thinking independently is punished: "And there the individual becomes as undistinguished member of a collectivist state. His chemical components are separated and poured into vats containing the corresponding elements of countless others" [1, p. 775]. Misfits and outlaws gathered there, with the implicit understanding that there was no way out but dying. Kilroy cannot accept it. He has more life about him, more hope. He hates to be trapped and yearns to break through the city walls and escape on il fugitive which might perhaps take him to another ring of hell. As the Camino protagonist is buried, he is encouraged to be thought of "as he was before his luck failed him", during the time of his "greatness, when he was not faded, not frightened" [1, p. 835].

Camino was difficult for Americans because "its moments of darkness contradicted an intrinsic American optimism" [4, p. 85]. However Williams's politics are humanitarian, not partisan. All his plays call for a deep human bond between people, for romantic quixotry. By romanticism he meant the ability to feel tenderness toward another human being, the ability to love. His romantic characters are often in conflict with the harsh material world, which brings about a collapse of culture and its myths. Yet their tragic sensibilities are humane and creative. The working title for Orpheus Des- 
cending was The Battle of Angels. In that battle the angels were defeated. Williams's characters seldom win. It is not the victory but the struggle itself that counts.

"We are all of us sentenced to solitary confinement in our own skins", says the character in Orpheus Descending. The barriers, walls and curtains in his plays symbolically denote the isolation between individuals and the impossibility of communication. Williams most definitely identified himself with Blanche from A Streetcar Named Desire. The home in A Streetcar is an environmental antagonist to Blanch. Her chief problem in the dirty, crowded, and oppressive apartment is that she is subject to too many disclosures at the hands of too many strangers, and on terms not her own. The flimsiness of walls, and the necessity to open windows guarantee that the Kowalski and the Hubbels will never be free from each other. Inside the apartment there are no doors, and there are only two rooms. Its inhabitants must dress and undress in the presence of each other. Nothing is safe from another person's scrutiny in such a place. Another detail is Blanche's trunk - it remains in a high-traffic area in Stanley and Stella's bedroom. Besides, Blanche's bed seems the most public place of all. Everything about that place metaphorically reinforces the permanent lack of privacy for Blanche. In his multilayered works nothing is simple. Williams never used symbols for the sake of frivolous images.

He insisted that symbols were "the natural speech of drama" and "a symbol in a play has only one legitimate purpose, which is to say a thing more directly and simply and beautifully than it could be said in words" [3, p. 70]. The image of caged birds is one of the leitmotifs Camino Real: the porters carry luggage - "which is mainly caged birds"; Marguerite and Jacques are referred to as "a pair of captive hawks, caught in the same cage" - the metaphor that best describes the nature of their relationship. Williams establishes "violets in the mountains" as the symbol of love and tenderness, and he uses it to the end when Quixote exclaims: "The violets in the mountains have broken the rocks!" The dried up fountains in the center of the plaza stand for the universal loss of communication with its accompanying pragmatism and materialism. Gutman and his thugs, who ruthlessly rule Camino Real metaphorically render Williams's criticism of any authoritarian regime, past as well as present.

In Williams's own words, the brutalities, madness, rape, and murder in his plays metaphorically represent "what society is doing to individuals" [9, p. 50]. The role of an artist, therefore, is defined by the playwright not as the one of a legislator, but rather as "a visionary", "a soothsayer". You won't find a harsh attack on the contemporary society in Williams's plays. Tennessee Williams ironically concludes in one of his interviews that he would be happy if people would just "read newspapers with a different eye" [9, p. 52]. Despite his irony, Williams believes that art can really make a difference, enabling people to make a moral judgement: "It should act as catharsis and purify them of the violence within themselves" [9, p. 54]. Williams concludes Camino Real with a prayer to return to the ideals of valor and dignity to the world. In other words, love, beauty and imagination ultimately triumph over cruelty, violence, and mendacity.

\section{REFERENCES}

1. Williams, T. Camino Real. New York: New Directions Book. 2008. 170 pp.

2. The Theatre of Tennessee Williams. Vol. 3. New York: New Directions Book. 1991. 423 pp.

3. Williams T. New selected essays: Where I Live. New York: New Directions Book, 2009. 256 pp.

4. Balakian J. Camino Real: Williams's Allegory about the Fifties // The Cambridge Companion to Tennessee Williams / Ed. Matthew C. Roudané. Cambridge: Cambridge UP, 1998. Pp. 67-94.

5. Bigsby C. W. Entering "The Glass Menagerie" // The Cambridge Companion to Tennessee Williams. / Ed. Matthew C. Roudané. Cambridge: Cambridge UP, 1998. Pp. 29-44. 
6. Faulkner W. On Privacy: the American Dream: What Happened to it // Harper's Magazine, July 1955.

7. Fisher J. Camino Real // Tennessee Williams: A Guide to Research and Performance / Ed. Philip C. Kolin. Westport, Conn.: Greenwood Press, 1998. Pp. 100-107.

8. Leverich L. Tom: The Unknown Tennessee Williams. New York: Crown. 1995. 678 pp.

9. Prism International. A Journal of Contemporary Writing. Spring 1981.

10. Robinson M. The Other American Drama // PAJ Publications. 2005. 218 pp. 